\title{
Editorial
}

\section{Studies on contrast sensitivity: a special section of Psychology $\&$ Neuroscience to honor the career of Eduardo Oswaldo Cruz}

\author{
Luiz Carlos L. Silveira ${ }^{1}$ and Dora F. Ventura ${ }^{2}$ \\ 1 - Universidade Federal do Pará, Belém, PA, Brazil. \\ 2 - Universidade de São Paulo, São Paulo, SP, Brazil
}

\section{Introduction}

Eduardo Oswaldo Cruz has dedicated his entire scientific career to the study of Visual Sciences. Several of his published works deal with different aspects of contrast sensitivity of the visual system in different animals. The visual system continuously samples the domains of space and time, measuring contrast at several spatiotemporal coordinates. This operation is constrained within the limits imposed by fundamental physics that are common to all sorts of devices whenever they sample a given domain to perform any kind of measurement (Silveira et al., 2008). Such constraints include the conflicting requirements to attain simultaneous precision in the domains of space and time, a problem that becomes particularly difficult when the visual system must perform its function at low levels of illumination (Silveira et al., 2008). This problem has been addressed in several ways by fully characterizing the spatial and temporal factors that affect information transfer along the visual system. Some of the key issues include the optical properties of eye dioptrics, spatial properties, and phototransduction phenomena of the photoreceptor matrix and the contrast transfer properties of neurons located in successive layers of the retina, thalamus, and visual cortex.

Some aspects of contrast sensitivity mechanisms were considered in a meeting organized by one of us, Luiz Carlos L. Silveira (UFPA), during the 2009 XXXIII Annual Meeting of the Brazilian Neuroscience and

Luiz Carlos L. Silveira, Universidade Federal do Pará, Núcleo de Medicina Tropical and Instituto de Ciências Biológicas, Belém, Brazil. Dora F. Ventura, Universidade de São Paulo, Instituto de Psicologia and Núcleo de Neurociências e Comportamento, São Paulo, Brazil. Correspondence regarding this article should be directed to: Dr. Luiz Carlos L. Silveira, Universidade Federal do Pará, Núcleo de Medicina Tropical, Av. Generalíssimo Deodoro, no 92 (Umarizal), 66055-240 Belém, Pará, Brazil. Phone: +5591-32016819. Fax:+5591-32410032. E-mail: luiz@ufpa.br
Behavior Society (SBNeC) held in Águas de Lindóia, São Paulo. This meeting, "The Contrast Sensitivity of the Visual System - A Symposium in Honor of Eduardo Oswaldo Cruz," consisted of four talks that dealt with problems that extend from the retina to the visual cortex and visual psychophysics: "Contrast sensitivity of retinal ganglion cells" (Barry B. Lee, State University of New York), "Contrast sensitivity of cortical neurons" (Ricardo Gattass and Mario Fiorani, UFRJ), "Contrast sensitivity and visual evoked potentials" (Luiz Carlos de Lima Silveira, UFPA), and "Contrast sensitivity and visual psychophysics" (Dora Fix Ventura, USP).

This special section of Psychology \& Neuroscience continues and expands the information presented in this meeting by publishing several studies on related subjects: "Single-pass measurement of the optical quality of the opossum eye" (Oswaldo-Cruz, Picanço-Diniz, and Silveira), "Contrast sensitivity and retinal ganglion cell responses in the primate" (Lee and Sun), "Cortical representation of the horizon in $\mathrm{V} 1$ and peripheral scaling in lateral eyed-mammals" (Picanço-Diniz, Rocha, Silveira, Elston, and Oswaldo-Cruz), "Comparative neurobiology of spatial luminance contrast sensitivity" (Souza, Gomes, and Silveira), "Enriched environment contributes to recovery of visual acuity and increases perineuronal nets in monocular deprived animals" (Trévia, Frota-de-Almeida, Sampaio, Warwick, Marques, dos Santos, Paulo, Viegas, and Picanço-Diniz), "Lateral interactions in visual perception of temporal signals: cortical and subcortical components" (Teixeira, Silveira, and Kremers) and "Psychophysical measurements of luminance and chromatic spatial and temporal contrast sensitivity in Duchenne muscular dystrophy" (Costa, Barboni, and Ventura).

\section{The Brazilian Neuroscience Medal}

The Symposium in Honor of Eduardo Oswaldo Cruz was followed by a ceremony that awarded him the 
prestigious Brazilian Neuroscience Medal. This award was created by the Brazilian Neuroscience and Behavior Society (SBNeC) 2005-2008 Society's Board of Directors, with Stevens Kastrup Rehen (UFRJ) as President. Since 2006, the Brazilian Neuroscience Medal has been regularly awarded during the $\mathrm{SBNeC}$ Annual Meeting to a Brazilian neuroscientist who has demonstrated outstanding contributions to the field of neuroscience. From 2006 to 2008, this medal was awarded to Carlos Eduardo Guinle da Rocha Miranda (UFRJ), Iván Antônio Izquierdo (PUC-RS), and Frederico Guilherme Graeff (USP-RP), respectively. On the $\mathrm{SBNeC}$ website, readers can watch short movies about the awardees and obtain much information about the current affairs of Brazilian neuroscience (http://www.sbnec.org.br/site/).

In 2009, during the XXXIII Annual Meeting of the $\mathrm{SBNeC}$, the Brazilian Neuroscience Medal was awarded to Eduardo Oswaldo Cruz. The ceremony was chaired by Marcus Vinícius Chrysóstomo Baldo, SBNeC President, and had a large audience that included the presidents of all FeSBE-affiliated scientific societies. Closing the ceremony, Luiz Eugênio Araújo de Moraes Mello(UNIFESP), FeSBE's President, addressed the young graduate and undergraduate students in the audience, telling them that their quest for knowledge consists of the rigorous use of the scientific method combined with a passion for enlarging scientific frontiers. This Psychology \& Neuroscience Editorial presents the 2009 awardee's biographical highlights.

\section{Eduardo Oswaldo Cruz}

Eduardo Oswaldo Cruz (http://www.abc.org.br/ resultado.php3? codigo=eocruz) was born in Rio de Janeiro on October 25, 1933, where he did his first studies in the Colégio Padre Antônio Vieira. In 1954, following the medical vocation of his family, he entered the National Medical Faculty of the Brazil University (which later became UFRJ) and immediately began attending several basic medical and biological sciences laboratories. In the beginning, he was associated with the Histology Chair under the supervision of Bruno Alípio Lobo, collaborating in research and teaching activities, in the translation of the textbook Histology by Arthur Worth Ham, and in the preparation of the textbook Embriologia Humana by Bruno Lobo himself.

Still in his first year of the medical course, Oswaldo Cruz became the monitor of the Physiology Chair under the supervision of Thales César Martins. Most of his time was dedicated to helping Arnoldo Flávio da Rocha e Silva and Mario Vianna Dias by preparing demonstrations and laboratory classes. With Mario Vianna Dias, he began experimental work in the Neurophysiology Sector of the Institute of Neurology, Brazil University. With the arrival of Denise Albe-Fessard to work in the Biophysics Institute at Brazil University, Oswaldo Cruz joined the group of young students who worked with her and published his first work on neurophysiology in 1956, first as an abstract and later as a full paper that was published in Anais da Academia Brasileira de Ciências (Oswaldo-Cruz, Rocha-Miranda, Paes-de-Carvalho, \& Albe-Fessard, 1956). Among the co-authors of this historical publication were Carlos Eduardo Guinle da Rocha Miranda and Antonio Paes de Carvalho, who would become two of the most important Brazilian physiologists. In 1956, Oswaldo Cruz moved to the Biophysics Institute, where he made a career first as an undergraduate and graduate student and then as a full professor of the Neurobiology Department. Oswaldo Cruz and Carlos Eduardo Rocha Miranda were invited by Denise Albe-Fessard to visit the Institute Marey in Paris, France, during the European winter the next 2 years (1956-1957), where they performed additional work under the guidance of this eminent French scientist. After defending his doctoral thesis in Medicine (Biophysics) at Brazil University (Oswaldo Cruz, 1961), he traveled to the United States for a postdoctoral position with Vernon Benjamin Mountcastle in the Department of Physiology at Johns Hopkins University in Baltimore, Maryland, supported by a fellowship from the National Institutes of Health (Figure 1).

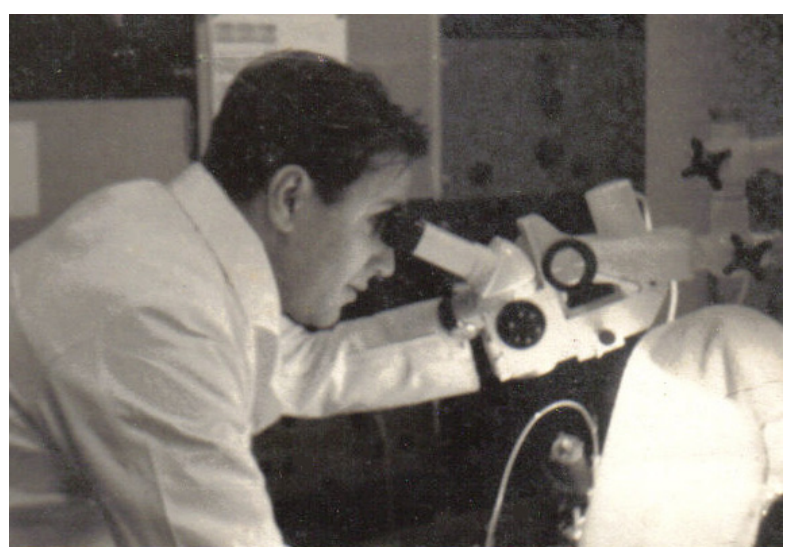

Figure 1. Eduardo Oswaldo Cruz during his postdoctoral training in the United States. At that time, he worked with Vernon Benjamin Mountcastle in the Department of Physiology at Johns Hopkins University in Baltimore, Maryland, supported by a fellowship from the National Institutes of Health (1961-1963). During his postdoctoral stage, he investigated several aspects of the somatic sensory system using electrophysiological and morphological techniques.

Eduardo Oswaldo Cruz returned to Brazil in 1963. With the support of a research grant awarded by the National Institutes of Health, he began a lengthy project to study the extrapyramidal system of marsupials. Among several publications that resulted from this project, he co-authored with Carlos Eduardo Rocha Miranda a cytoarchitectonic atlas in stereotaxic coordinates of the opossum Didelphis marsupialis (Oswaldo-Cruz \& RochaMiranda, 1968). During most of his career, Oswaldo Cruz was a Professor at the Carlos Chagas Filho Biophysics 
Institute, UFRJ, and published several works on the nervous systems of primates, felines, rodents, marsupials, and invertebrates using various methods that encompass electrophysiology (Gattass, Oswaldo-Cruz, \& Sousa, 1978; Gattass, Sousa, \& Oswaldo-Cruz, 1978; OswaldoCruz et al., 1956; Oswaldo-Cruz, 1961; Picanço-Diniz, Silveira, \& Oswaldo-Cruz, 1983; Picanço-Diniz, Silveira, de Carvalho, \& Oswaldo-Cruz, 1991; Silveira, PicançoDiniz, \& Oswaldo-Cruz, 1982; Sousa, Oswaldo-Cruz, \& Gattass, 1971), anatomy, histology, optical microscopy, electronic microscopy (Hokoç \& Oswaldo-Cruz, 1978; Hokoç \& Oswaldo-Cruz, 1979; Oswaldo-Cruz \& RochaMiranda, 1968; Oswaldo-Cruz \& Bernardes, 1982; Picanço-Diniz, Oliveira, Silveira, \& Oswaldo-Cruz, 1989; Silveira, Picanço-Diniz, \& Oswaldo-Cruz, 1989), physiological optics (Oswaldo-Cruz, Hokoç, \& Sousa, 1979; Picanço-Diniz et al., 1983), computer science (Zin \& Oswaldo-Cruz, 1981), and linear system analysis (Silveira et al., 1982). The graduate and undergraduate students who were supervised by Oswaldo Cruz during his long career are now teachers and scientists themselves at several Brazilian institutions and are able to pass along to their own students the large variety of techniques and scientific procedures that they learned from him. He also extended this contribution to scientists from neighboring areas who were frequently invited to participate in memorable $\mathrm{PhD}$ and Master's degree examination committees, where a large and participating audience always filled the main auditorium at the Biophysics Institute at the Federal University of Rio de Janeiro. In turn, he agreed to participate in similar committees at other institutions, and his expert analysis of the topic at hand was always appreciated as the final word.

Oswaldo Cruz made very important contributions to Brazilian Neuroscience by collaborating with many Brazilian scientists and former students to establish new research groups at many different institutions, among them the Neurophysiology Laboratory in the Department of Biology at UnB and the Excitable Tissues Laboratory (which was later renamed the Eduardo Oswaldo Cruz Neurophysiology Laboratory) in the Biological Sciences Institute at UFPA (Figure 2).

His knowledge of the country's course of the development of science in general and neuroscience in particular was derived from his active participation and remarkable memory of events, participants, and issues, which he often conveyed to small groups by using witty anecdotes. The most recent such session occurred in 2007 with a large audience that consisted mainly of young students who gathered with him for a chat at the formal auditorium of the Tropical Medicine Nucleus, Federal University of Pará. The students witnessed three hours of enlightened historical analysis of the scientific situation in Brazil. The audience left with an important grasp of a part of our Brazilian history seen through a master's sophisticated eyes.

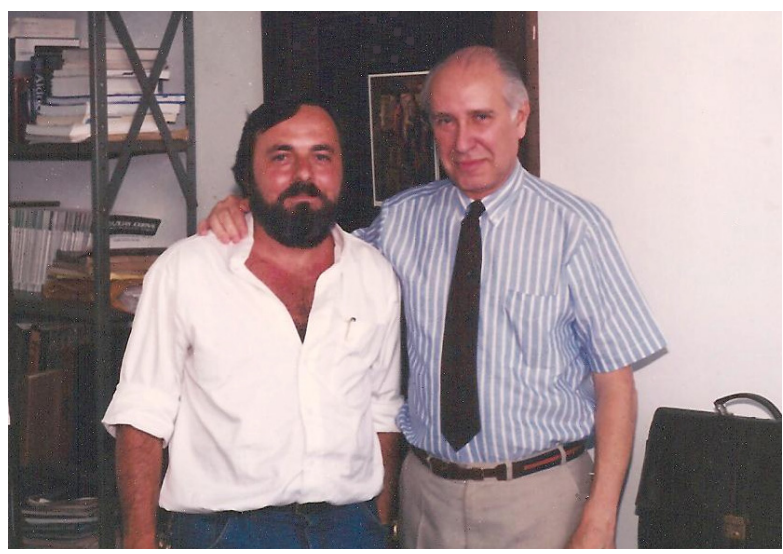

Figure 2. Eduardo Oswaldo Cruz and Cristovam Wanderley Picanço Diniz. Cristovam Picanço Diniz completed his MSc (1980) and $\mathrm{PhD}$ (1987) at UFRJ under the supervision of Oswaldo Cruz and did his postdoctoral work (1989) at the University of Oxford with Kevan A.C. Martin. Cristovam Picanço Diniz is one of several of Oswaldo Cruz's students who successfully replicated the scientific, academic, and ethical principles that they learned from him and now teach their own undergraduate and graduate students in neuroscience laboratories that are spread widely throughout many Brazilian institutions. This photograph was taken in 1991 in the Eduardo Oswaldo Neurophysiology Laboratory at the Biological Sciences Institute, UFPA, in Belém, Pará.

Eduardo Oswaldo Cruz was Director of Casa do Brasil in London (1982-1992). During this time, with CNPq support, he worked on a project to support Brazilian graduate students and postdoctoral fellows in the United Kingdom. He also attended the Vision Research Unit at Rayne Institute and was a Visiting Professor at St. Thomas Hospital Medical School, working with Hisako Ikeda.

Eduardo Oswaldo Cruz was also very active in science administration as a member of several regional and national committees, including the $\mathrm{CNPq}$ Committee for Biophysics, Biochemistry, Physiology, and Pharmacology. At CNPq, he was a member of the prestigious Group of Lecturer Scientists that later became the Grade 1A CNPq Research Fellows. He was General Secretary of the Brazilian Academy of Sciences (1981-1983) and the Academy representative in the United Kingdom (1993). In the Academy, he collaborated with Aristides Azevedo Pacheco Leão in establishing the John E. Fogarty International Center Advancing Science for Global Health fellowship program (1978-1980), the joint Brazil-Japan program with the Japan Society, and the joint Brazil-United Kingdom program with the Royal Society.

For his outstanding contribution to Brazilian science, Eduardo Oswaldo Cruz was awarded the Federal University of Pará Silver Palm (1983), Brazilian National Order of Scientific Merit - Grã-Cruz Level (1998; awarded by the country's President, Fernando Henrique Cardoso), and Brazilian Neuroscience Medal (2009; awarded by the Brazilian Society of Neuroscience and Behavior). 
Eduardo Oswaldo Cruz is married to Lílian Oswaldo Cruz, who always took part in his professional life, hosting lively home gatherings to celebrate important occasions, including $\mathrm{PhD}$ receptions where committee members gathered with graduate students and faculty. They have four children and several grandchildren.

Eduardo Oswaldo Cruz's disciples have populated many scientific and technological institutions throughout Brazil and have been actively involved in disseminating the excellent education they received from him and his wife (Figure 3).

\section{The crystal cave}

In the first steps of his fundamental work, History of Western Philosophy, the Welsh philosopher, mathematician, and historian Bertrand Arthur William Russell (1872-1970) first confronts us with an attempt to understand the universe through science as opposed to other forms of relationships with this same universe:

Science tells us what we can know, but what we can know is little, and if we forget how much we cannot know we become insensitive to many things of very great importance ... To teach how to live without certainty, and yet without being paralised by hesitation, is perhaps the chief thing that philosophy, in our age, can still do for those who study it. (Russell, 2004, p.2)

Later, when he begins to teach us about the beginnings of Western Philosophy among the Greeks and warn us about the Olympic and Bacchic elements of Greek religion, which opposed each other and unfolded during the centuries when the Greeks created things that matter even today, Bertrand Russell comments on this permanent duality of the human mind:

Much of what is greatest in human achievement involves some element of intoxication, some sweeping away of prudence by passion. Without the Bacchic element, life would be uninteresting; with it, it is dangerous. Prudence versus passion is a conflict that runs through history. It is not a conflict in which we ought to side wholly with either party. In the sphere of thought, sober civilization is roughly synonymous with science. But science unadulterated, is not satisfying; men may set passion and art and religion. Science may set limits to knowledge, but should not set limits to imagination. (Russell, 2004, p.16).

So to the teachers is left the task to find the delicate balance between prudence and passion, which are the driving forces and steering principles of Scientific Initiation. Their disciples come and go, and when they go, new students arrive at the same time the first students fade into a progressively more distant horizon. In the Merlin Trilogy (Stewart, 1970, 1973, 1979), the English novelist Mary Florence Elinor Rainbow (Stewart) (1916-) initially describes the first meeting between Merlin and his mentor Galapas in the Crystal

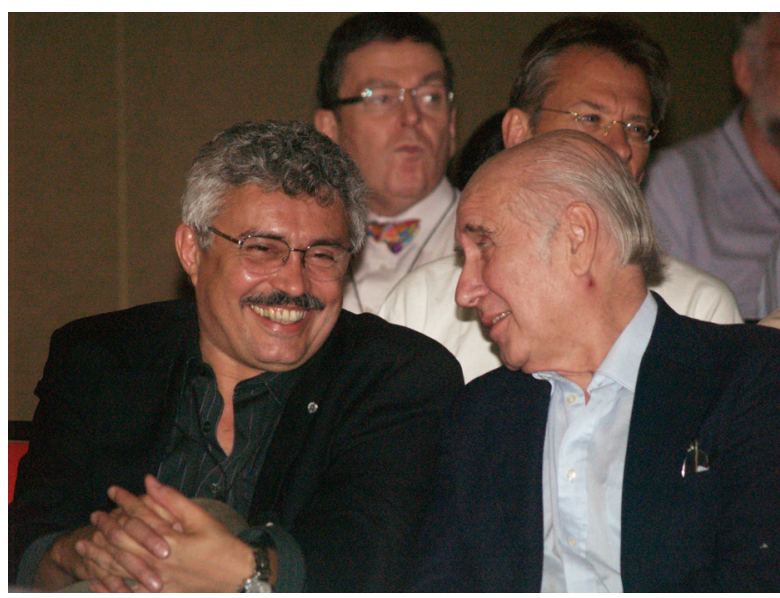

Figure 3. Eduardo Oswaldo Cruz and Luiz Carlos de Lima Silveira. Luiz Carlos Silveira completed his MSc (1980) and $\mathrm{PhD}(1985)$ at UFRJ with Eduardo Oswaldo Cruz and later performed his postdoctoral work at the University of Oxford with Alan Cowey. This photograph was taken during the $19^{\text {th }}$ Biannual Symposium of the International Colour Vision Society in Belém, Pará (2007).

Cave where Galapas lived, studied, and performed his experiments:

Myrddin - There was a god at the spring outside (...).

Galapas - Yes, Myrddin. He lends me his spring, and his hollow hill, and his heaven of woven light, and in return I give him his due. It does not do to neglect the gods of a place, whoever they may be. In the end, they are all one.

Myrddin - If you're not a hermit, then, what are you?

Galapas - At the moment, a teacher." (Stewart, 1970, pp. 30-31).

Thirteen hundred pages later and decades after the above episode, Mary Stewart takes us back to the Crystal Cave to hear how Merlin describes one of his encounters with his disciple Arthur:

I saw him raise a hand.

- Wait for me.

It was the same farewell always.

- Wait for me. I shall come back.

And, as ever, I made the same reply:

- What else have I to do but wait for you? I shall be here, when you come again.

The sound of horses dwindled, faded, was gone. The winter's silence came back to the valley. The dark drew down. (Stewart, 1979, p.1388).

\section{Acknowledgements}

This short biography of Eduardo Oswaldo Cruz was partially published previously in Portuguese (Silveira, 2009). The Psychology \& Neuroscience editors are 
grateful to Editora Atlântica for permission to use this material. LCLS and DFV are CNPq research fellows.

\section{References}

Gattass, R., Oswaldo-Cruz, E., \& Sousa, A.P.B. (1978). Visuotopic organization of the Cebus pulvinar: a double representation of the contralateral hemifield. Brain Research, 152, 1-16.

Gattass, R., Sousa, A.P.B., \& Oswaldo-Cruz, E. (1978). Single unit response types in the pulvinar of Cebus monkey to multisensory stimulation. Brain Research, 158, 75-87.

Hokoç, J.N., \& Oswaldo Cruz, E. (1978). Quantitative analysis of the opossum's optic nerve: an electron microscope study. Journal of Comparative Neurology, 178, 773-782.

Hokoç, J.N., \& Oswaldo-Cruz, E. (1979). A regional specialization in the opossum's retina: quantitative analysis of the ganglion cell layer. Journal of Comparative Neurology, 183, 385-395.

Oswaldo Cruz, E. (1961). Córtex "Associativo" do Cebus: Estudo Eletrofisiológico. (M.D. Thesis Biophysics). Instituto de Biofísica, Faculdade Nacional de Medicina, Universidade do Brasil.

Oswaldo Cruz, E., \& Bernardes, R.F. (1982). Morphological and functional observations on the eye of Strophocheilus (Mollusca Gastropoda Stylomatophora). Brazilian Journal of Medical and Biological Research, 15, 161-174.

Oswaldo-Cruz, E., Hokoç, J.N., \& Sousa, A.P.B. (1979). A schematic eye for the opossum. Vision Research, 19, 263-278.

Oswaldo-Cruz, E., \& Rocha-Miranda, C.E. (1968). The brain of the opossum (Didelphis marsupialis): a cytoarchitectonic atlas in stereotaxic coordinates. Rio de Janeiro: Instituto de Biofísica, Universidade Federal do Rio de Janeiro.

Oswaldo Cruz, E., Rocha Miranda, C.E., Paes de Carvalho, A., \& AlbeFessard, D. (1956). Sobre algumas respostas encontradas no nucleus reticularis e na zona incerta por estimulação de nervos periféricos. Anais da Academia Brasileira de Ciências, 28, 515-521.

Picanço-Diniz, C.W., Oliveira, H.L.S., Silveira, L.C.L., \& Oswaldo-
Cruz, E. (1989). The visual cortex of the aguti (Dasyprocta aguti): architectonic subdivisions. Brazilian Journal of Medical and Biological Research, 22, 121-138.

Picanço-Diniz, C.W., Silveira, L.C.L., de Carvalho, M.S.P., \& Oswaldo-Cruz, E. (1991). Contralateral visual field representation in area 17 of the cerebral cortex of the agouti: a comparison between cortical magnification factor and retinal ganglion cell distribution. Neuroscience, 44, 325-333.

Picanço-Diniz, C.W., Silveira, L.C.L., \& Oswaldo-Cruz, E. (1983). Electrophysiological determination of the refractive state of the eye of the opossum. Vision Research, 23, 867-872.

Russell, B. (2004). History of Western philosophy. London: Routledge. First published: London: George Allen \& Unwin. (Original work published 1946).

Silveira, L.C.L. (2009). Eduardo Oswaldo Cruz, Medalha Neurociências Brasil 2009. Neurociências, 5, 123-129.

Silveira, L.C.L., Picanço-Diniz, C.W., \& Oswaldo-Cruz, E. (1982). Contrast sensitivity function and visual acuity of the opossum. Vision Research, 22, 1371-1377.

Silveira, L.C.L., Picanço-Diniz, C.W., \& Oswaldo-Cruz, E. (1989). The distribution and size of ganglion cells in the retinae of large Amazon rodents. Visual Neuroscience, 2, 221-235.

Silveira, L.C.L., Saito, C.A., de Mello Jr., H.D., Silveira, V.A., Souza G.S., Rodrigues, A.R., \& da Silva Filho, M. (2008). Division of labour between the $\mathrm{M}$ and $\mathrm{P}$ visual pathways: different visual pathways minimize joint entropy differently. Psychology \& Neuroscience, 1, 3-14.

Sousa, A.P.B., Oswaldo-Cruz, E., \& Gattass, R. (1971). Somatotopic organization and response properties of neurons of the ventrobasa complex in the opossum. Journal of Comparative Neurology, 142, 231-247.

Stewart, M. (1970). The crystal cave. New York: Fawcett Crest Books. Stewart, M. (1973). The hollow hills. New York: Fawcett Crest Books. Stewart, M. (1979). The last enchantment. New York: Fawcett Crest Books. Zin, W.A., \& Oswaldo-Cruz, E. (1981). AVG: a signal averager for biological data. International Journal of Biomedical Computing, 12, 149-156. 